\title{
In situ construction of heterostructured bimetallic sulfide/phosphide with rich interfaces for high-performance aqueous $\mathrm{Zn}$-ion batteries
}

\author{
Fang Yang ${ }^{1}$, Yuenian Shen ${ }^{2}$, Ze Cen ${ }^{1}$, Jie $\mathrm{Wan}^{1}$, Shijie $\mathrm{Li}^{3^{*}}$, Guanjie $\mathrm{He}^{4}$, Junqing $\mathrm{Hu}^{2,5}$ and Kaibing $\mathrm{Xu}^{2 *}$
}

\begin{abstract}
It is still challenging to develop suitable cathode structures for high-rate and stable aqueous $\mathrm{Zn}$-ion batteries. Herein, a phosphating-assisted interfacial engineering strategy is designed for the controllable conversion of $\mathrm{NiCo}_{2} \mathrm{~S}_{4}$ nanosheets into heterostructured $\mathrm{NiCoP} / \mathrm{NiCo}_{2} \mathrm{~S}_{4}$ as the cathodes in aqueous $\mathrm{Zn}$-ion batteries. The multicomponent heterostructures with rich interfaces can not only improve the electrical conductivity but also enhance the diffusion pathways for $\mathrm{Zn}$-ion storage. As expected, the $\mathrm{NiCoP} / \mathrm{NiCo}_{2} \mathrm{~S}_{4}$ electrode has high performance with a large specific capacity of $251.1 \mathrm{~mA} \mathrm{~h} \mathrm{~g}^{-1}$ at a high current density of $10 \mathrm{~A} \mathrm{~g}^{-1}$ and excellent rate capability (retaining about $76 \%$ even at $50 \mathrm{~A} \mathrm{~g}^{-1}$ ). Accordingly, the $\mathrm{Zn}$-ion battery using $\mathrm{NiCoP} / \mathrm{NiCo}_{2} \mathrm{~S}_{4}$ as the cathode delivers a high specific capacity $\left(265.1 \mathrm{~mA} \mathrm{~h} \mathrm{~g}^{-1}\right.$ at $5 \mathrm{~A} \mathrm{~g}^{-1}$ ), a long-term cycling stability $(96.9 \%$ retention after 5000 cycles), and a competitive energy density $(444.7 \mathrm{~W} \mathrm{~h} \mathrm{~kg}$ at the power density of $8.4 \mathrm{~kW} \mathrm{~kg}^{-1}$ ). This work therefore provides a simple phosphating-assisted interfacial engineering strategy to construct heterostructured electrode materials with rich interfaces for the development of high-performance energy storage devices in the future.
\end{abstract}

Keywords: phosphating, heterostructure, $\mathrm{NiCoP} / \mathrm{NiCo}_{2} \mathrm{~S}_{4}, \mathrm{Zn}$ ion batteries, high capacity

\section{INTRODUCTION}

To alleviate the excessive consumption of traditional fossil fuels and increasing environmental pollution issues, it is particularly urgent and important to develop high-efficiency and clean energy storage devices. Typically, lithium (Li)-ion batteries have been widely used in a variety of energy storage systems, such as portable electronics, electric vehicles, and grid-scale energystorage systems [1]. However, the large-scale application of Liion batteries is still a huge challenge because of limited lithium resources and toxic organic electrolytes [2-5]. Recently, researchers have focused on the exploration of high-performance aqueous rechargeable batteries with low cost and reliable safety [6-10]. Among various rechargeable batteries, aqueous $\mathrm{Zn}$-ion batteries are emerging as one of the most competitive candidates to replace Li-ion batteries by virtue of the high the- oretical capacity of the zinc anode $\left(820 \mathrm{~mA} \mathrm{~h} \mathrm{~g}^{-1}\right)$, high working voltage $(\sim 1.8 \mathrm{~V})$, as well as its low cost and low toxicity [11-20]. However, the unsatisfactory energy/power density and poor cycling stability severely limit their practical application. Designing and constructing highly active cathode materials has been demonstrated as a promising strategy to improve the performance of $\mathrm{Zn}$-ion batteries.

Transition metal sulfides have been extensively investigated as electrode materials due to their higher electronic conductivity and better reversible electrochemical properties than those of their oxide counterparts [21-24]. Especially, $\mathrm{NiCo}_{2} \mathrm{~S}_{4}$ electrode materials have been proved to have better electronic conductivities of about 100 times higher than that of $\mathrm{NiCo}_{2} \mathrm{O}_{4}$ $[21,25]$. In addition, compared with its corresponding singlecomponent sulphides $\left(\mathrm{NiS}_{x}\right.$ and $\left.\mathrm{CoS}_{x}\right), \mathrm{NiCo}_{2} \mathrm{~S}_{4}$ has significantly richer redox reactions because of multiple available oxidation states and faster electron transfer properties [26,27]. For instance, Han et al. [28] developed sulfur-deficient $\mathrm{NiCo}_{2} \mathrm{~S}_{4-x}$ nanotube arrays on carbon cloth as an effective cathode material for flexible $\mathrm{Zn}$ batteries, which delivered a high capacity of $298.3 \mathrm{~mA} \mathrm{~h} \mathrm{~g}^{-1}$ at $0.5 \mathrm{Ag}^{-1}$ and superior rate capability. On the other hand, transition metal phosphides have attracted extensive research interest due to their unique electronic structure and high thermal/chemical stability, which show high electrocatalytic activity/durability and good conductivity [29-33]. For example, Zhang et al. [34] developed ultrafine and highly active bimetallic $\mathrm{Co}_{x} \mathrm{Ni}_{1-x} \mathrm{P}$ nanoparticles loaded on carbon nanofibers, exhibiting an extraordinary specific capacitance of $3514 \mathrm{Fg}^{-1}$ at $5 \mathrm{Ag} \mathrm{g}^{-1}$. Therefore, the in-situ construction of metal phosphides based on metal sulfides can effectively realize the coupling of their respective advantages. Furthermore, constructing novel multicomponent heterostructures with metal sulfides and phosphides is emerging as an effective strategy to generate abundant interfaces for fast charge transfer and to improve the number of highly exposed active sites for redox reactions, showing great application potential.

In this study, we developed a controllable route to fabricate heterostructured $\mathrm{NiCoP} / \mathrm{NiCo}_{2} \mathrm{~S}_{4}$ nanosheet arrays on carbon cloth as electrode, which showed the strong synergistic effect and rich interfaces between $\mathrm{NiCoP}$ and $\mathrm{NiCo}_{2} \mathrm{~S}_{4}$, and delivered a high specific capacity of $251.1 \mathrm{~mA} \mathrm{~h} \mathrm{~g}^{-1}$ at a high current density

\footnotetext{
${ }^{1}$ School of Mechanical and Automotive Engineering, Shanghai University of Engineering Science, Shanghai 201620, China

${ }^{2}$ State Key Laboratory for Modification of Chemical Fibers and Polymer Materials, Research Center for Analysis and Measurement \& College of Materials Science and Engineering, Donghua University, Shanghai 201620, China

${ }^{3}$ Institute of Innovation \& Application, National Engineering Research Center for Marine Aquaculture, Zhejiang Ocean University, Zhoushan 316022, China

${ }^{4}$ School of Chemistry, University of Lincoln, Brayford Pool, Lincoln LN6 7TS, UK

${ }^{5}$ College of Health Science and Environmental Engineering, Shenzhen Technology University, Shenzhen 518118, China

* Corresponding authors (emails: lishijie@zjou.edu.cn (Li S); xukaibing@dhu.edu.cn (Xu K))
} 
of $10 \mathrm{Ag}^{-1}$ and excellent rate capability. The aqueous $\mathrm{Zn}$-ion battery based on $\mathrm{NiCoP} / \mathrm{NiCo}_{2} \mathrm{~S}_{4}\left(\mathrm{NiCoP} / \mathrm{NiCo}_{2} \mathrm{~S}_{4} / / \mathrm{Zn}\right.$ battery) delivered a high specific capacity of $265.1 \mathrm{~mA} \mathrm{~h} \mathrm{~g}^{-1}$ at $5 \mathrm{~A} \mathrm{~g}^{-1}$ and good cycling stability (capacity retention of $96.9 \%$ after 5000 cycles). Moreover, this battery possessed a high energy density of $444.7 \mathrm{~W} \mathrm{~h} \mathrm{~kg}^{-1}$ at the power density of $8.4 \mathrm{~kW} \mathrm{~kg}^{-1}$. This study verifies that establishing transition metal sulfides and phosphides heterostructured materials for enhancing the energy storage performance of aqueous $\mathrm{Zn}$-ion batteries is efficient.

\section{EXPERIMENTAL SECTION}

\section{Synthesis of $\mathrm{NiCo}_{2} \mathrm{~S}_{\mathbf{4}}$ nanosheet arrays}

$\mathrm{Ni}\left(\mathrm{NO}_{3}\right)_{2} \cdot 6 \mathrm{H}_{2} \mathrm{O}(1 \mathrm{mmol}), \mathrm{Co}\left(\mathrm{NO}_{3}\right)_{2} \cdot 6 \mathrm{H}_{2} \mathrm{O}(2 \mathrm{mmol})$, and hexamethylenetetramine $(5.7 \mathrm{mmol})$ were dissolved in deionized water $(25 \mathrm{~mL})$ and ethanol $(25 \mathrm{~mL})$ under vigorous stirring. The resulting pink solution was then transferred into a $60-\mathrm{mL}$ stainless steel autoclave with a piece of pretreated carbon cloth $(1 \mathrm{~cm} \times 4 \mathrm{~cm})$ and sealed at $95^{\circ} \mathrm{C}$ for $8 \mathrm{~h}$. Subsequently, the obtained precursor on carbon cloth was annealed in air at $350^{\circ} \mathrm{C}$ for $2 \mathrm{~h}$, to obtain $\mathrm{NiCo}_{2} \mathrm{O}_{4}$. Finally, the above carbon cloth was immersed in $50 \mathrm{~mL}$ of deionized water with $1 \mathrm{~g}$ of $\mathrm{Na}_{2} \mathrm{~S} \cdot 9 \mathrm{H}_{2} \mathrm{O}$, and maintained at $100^{\circ} \mathrm{C}$ for $24 \mathrm{~h}$ to obtain $\mathrm{NiCo}_{2} \mathrm{~S}_{4}$ samples.

\section{Synthesis of $\mathrm{NiCoP} / \mathrm{NiCo}_{2} \mathrm{~S}_{4}$ nanosheet arrays}

To fabricate the $\mathrm{NiCoP} / \mathrm{NiCo}_{2} \mathrm{~S}_{4}$ nanosheet arrays, the $\mathrm{NiCo}_{2} \mathrm{~S}_{4}$ nanosheet arrays on carbon cloth were annealed under $\mathrm{N}_{2}$ atmosphere with the presence of $\mathrm{NaH}_{2} \mathrm{PO}_{2}(0.25-1 \mathrm{~g})$ at 350$450^{\circ} \mathrm{C}$ for $1-4 \mathrm{~h}$. The mass loadings of $\mathrm{NiCo}_{2} \mathrm{~S}_{4}$ and $\mathrm{NiCoP} /$ $\mathrm{NiCo}_{2} \mathrm{~S}_{4}$ materials were 0.60 and $0.63 \mathrm{mg} \mathrm{cm}^{-2}$, respectively. For comparison, the $\mathrm{NiCo}_{2} \mathrm{O}_{4}$ nanosheet arrays were prepared at $400^{\circ} \mathrm{C}$ for $2 \mathrm{~h}$ with $0.5 \mathrm{~g}$ of $\mathrm{NaH}_{2} \mathrm{PO}_{2}$ to obtain $\mathrm{NiCoP}$ nanosheet arrays.

\section{Materials characterization}

The as-obtained materials were investigated by scanning electron microscopy (SEM; Hitachi, S-4800), transmission electron microscopy (TEM; JEOL, JEM-2100F), X-ray diffractometer (XRD; Rigaku, D/max-2550 PC), X-ray photoelectron spectroscopy (XPS; Thermo Fisher, Escalab 250Xi), and BrunauerEmmett-Teller analyzer (BET; Quantachrome, Autosorb-iQ).

\section{Electrochemical measurement}

The electrochemical measurements were carried out on an electrochemical workstation (Metrohm Autolab PGSTAT302N, the Netherlands). A three-electrode system was assembled for the evaluation of electrochemical properties of individual electrodes in $1 \mathrm{~mol} \mathrm{~L}-1 \mathrm{KOH}$ aqueous solution. The $\mathrm{NiCoP} / \mathrm{NiCo}_{2} \mathrm{~S}_{4}$ nanosheet arrays on carbon cloth were used directly as the working electrode, with the saturated calomel electrode as a reference and a platinum plate as the counter electrode. The aqueous $\mathrm{Zn}$-ion battery was assembled using $\mathrm{NiCoP} / \mathrm{NiCo}_{2} \mathrm{~S}_{4}$ materials as the cathode and a piece of commercial $\mathrm{Zn}$ plate as the anode with the mixed solution of $1 \mathrm{~mol} \mathrm{~L}^{-1} \mathrm{KOH}$ and $0.01 \mathrm{~mol} \mathrm{~L}^{-1} \mathrm{Zn}\left(\mathrm{CH}_{3} \mathrm{COO}\right)_{2}$ as the electrolyte, and the twoelectrode configuration was constructed to assess the electrochemical performance of the as-fabricated batteries.

\section{RESULTS AND DISCUSSION}

Fig. 1 schematically illustrates the entire preparation procedure of heterostructured $\mathrm{NiCoP} / \mathrm{NiCo}_{2} \mathrm{~S}_{4}$ nanosheet arrays on carbon cloth. First, $\mathrm{NiCo}_{2} \mathrm{O}_{4}$ nanosheets are directly grown on the bare carbon cloth through a facile hydrothermal reaction, and calcined under air atmosphere to improve their crystallinity. After that, hydrothermal reaction is again employed to realize the phase transformation between $\mathrm{NiCo}_{2} \mathrm{O}_{4}$ and $\mathrm{NiCo}_{2} \mathrm{~S}_{4}$ by using $\mathrm{Na}_{2} \mathrm{~S} \cdot 9 \mathrm{H}_{2} \mathrm{O}$ as the sulfur source, where all the $\mathrm{O}^{2-}$ is exchanged into $\mathrm{S}^{2-}$ via the Kirkendall effect. Finally, to accomplish the interfacial engineering of $\mathrm{NiCO}_{2} \mathrm{~S}_{4}$, phosphate treatment is conducted with $\mathrm{NaH}_{2} \mathrm{PO}_{2}$ as the phosphorus source. During this process, newly formed NiCoP nanoparticles are embedded into $\mathrm{NiCo}_{2} \mathrm{~S}_{4}$ nanosheets, generating an updated heterostructured nanostructure with rich interfaces due to the higher electronegativity of $\mathrm{P}$ than those of $\mathrm{Ni}$ and $\mathrm{Co}$ [35]. The NiCoP/ $\mathrm{NiCo}_{2} \mathrm{~S}_{4}$ electrode prepared at $400^{\circ} \mathrm{C}$ for $2 \mathrm{~h}$ with $0.5 \mathrm{~g}$ of $\mathrm{NaH}_{2} \mathrm{PO}_{2}$ is discussed in the following sections, unless otherwise stated, as it shows the highest specific capacities.

The micromorphology of the $\mathrm{NiCo}_{2} \mathrm{~S}_{4}$ nanosheets on carbon cloth was preliminarily investigated by SEM and TEM (Fig. 2). The SEM images (Fig. 2a, b) show that the $\mathrm{NiCo}_{2} \mathrm{~S}_{4}$ nanosheets derived from $\mathrm{NiCo}_{2} \mathrm{O}_{4}$ nanosheets (Fig. S1) remain uniformly supported on the carbon cloth, and these nanosheets are interconnected to each other. In Fig. 2c, the TEM image of the $\mathrm{NiCo}_{2} \mathrm{~S}_{4}$ nanosheet shows numerous small pores uniformly distributed throughout the surface. The high-resolution TEM image (HRTEM) characterization clearly displays the lattice fringe with an interplanar distance of $0.332 \mathrm{~nm}$, well corresponding to the (220) plane of $\mathrm{NiCo}_{2} \mathrm{~S}_{4}$ (Fig. 2d). Furthermore, the energy dispersive X-ray spectroscopy (EDS) element mapping images (Fig. 2e) show the even distribution of $\mathrm{Ni}$, Co and $\mathrm{S}$

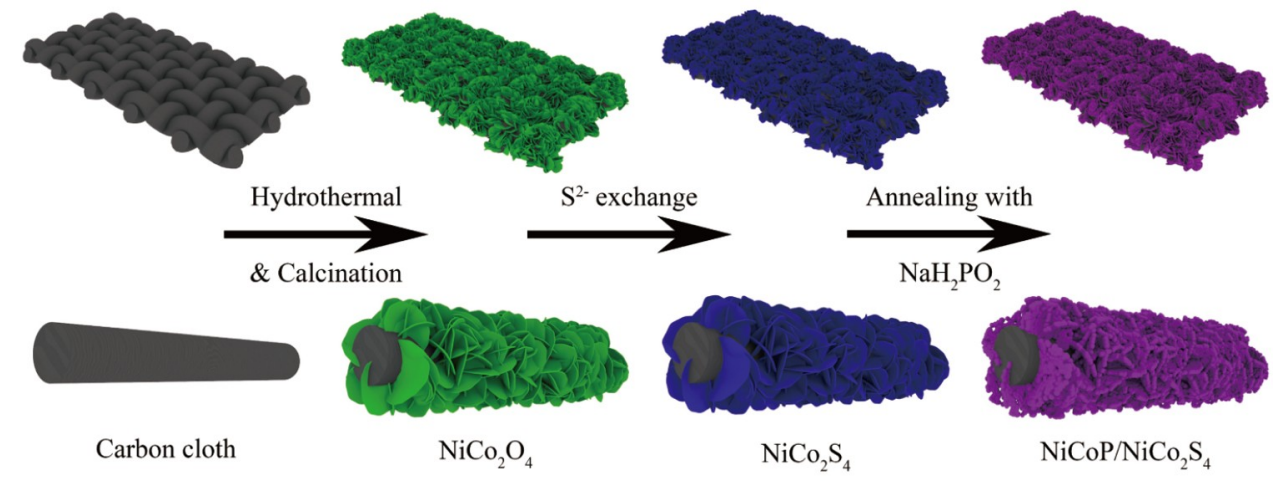

Figure 1 Schematic illustration of the heterostructured $\mathrm{NiCoP} / \mathrm{NiCo}_{2} \mathrm{~S}_{4}$ nanosheet arrays supported on carbon cloth. 

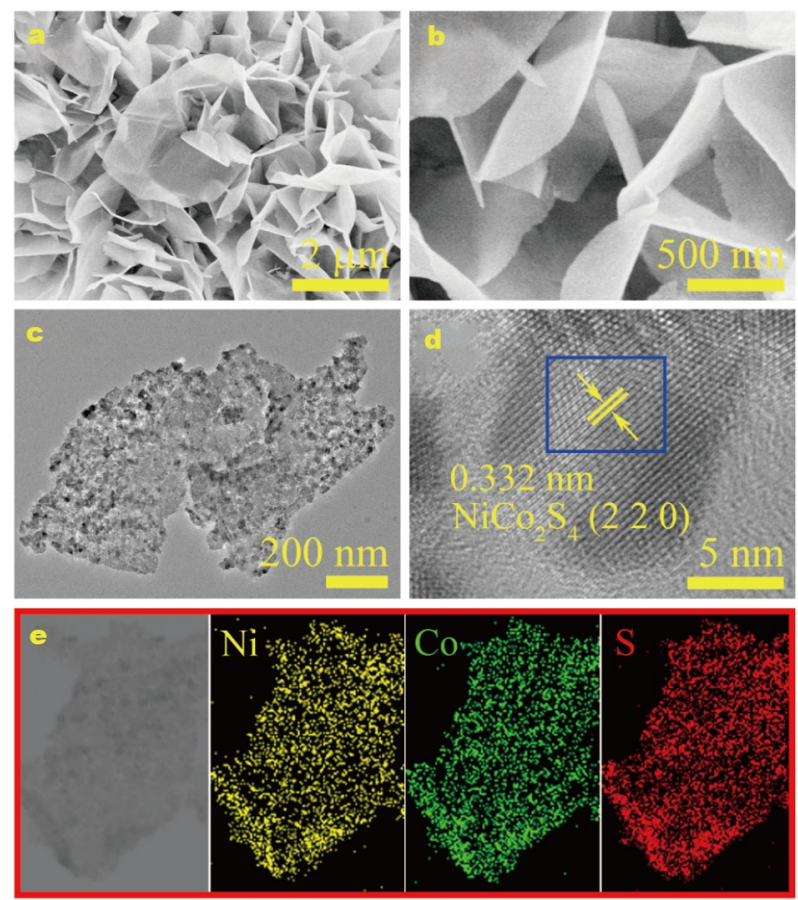

Figure 2 (a, b) SEM, (c) TEM, (d) HRTEM, and (e) elemental mapping images of the $\mathrm{NiCo}_{2} \mathrm{~S}_{4}$ nanosheets.
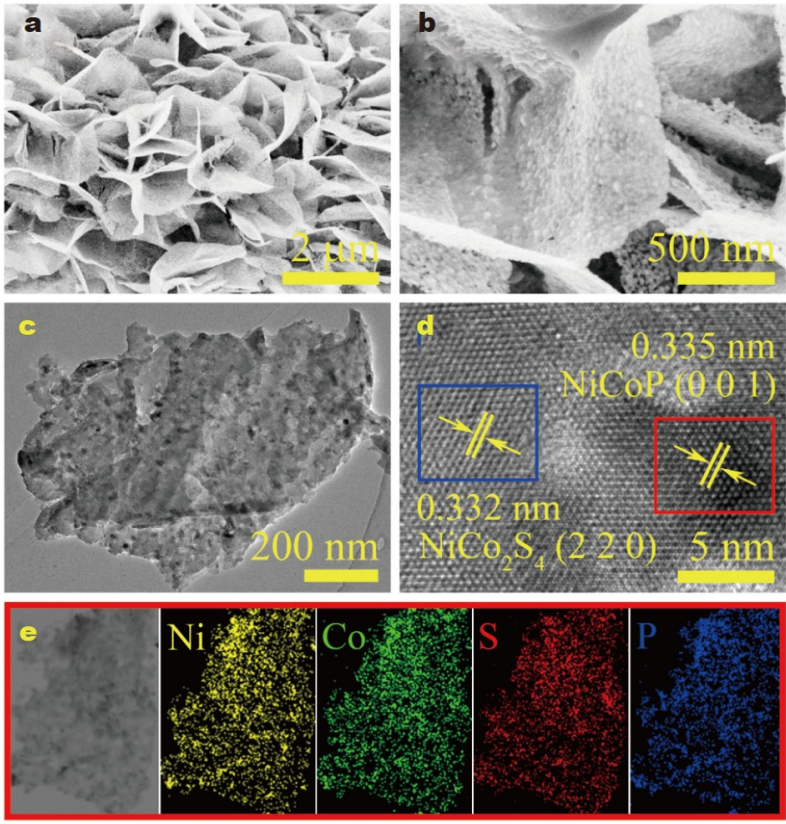

Figure 3 (a, b) SEM, (c) TEM, (d) HRTEM, and (e) the corresponding elemental mapping images of the $\mathrm{NiCoP} / \mathrm{NiCo}_{2} \mathrm{~S}_{4}$ nanosheets.

elements in the $\mathrm{NiCo}_{2} \mathrm{~S}_{4}$ nanosheet.

According to the SEM images of Fig. 3a, b, the densely packed and highly ordered $\mathrm{NiCoP} / \mathrm{NiCO}_{2} \mathrm{~S}_{4}$ nanosheet arrays are uniformly grown on the carbon cloth surface, and these nanosheets are interconnected to each other with plenty of spaces, which are beneficial to the charge transportation and ion diffusion, thus enhancing the specific capacity. Compared with $\mathrm{NiCo}_{2} \mathrm{~S}_{4}$ nanosheets, the surface of the $\mathrm{NiCoP} / \mathrm{NiCo}_{2} \mathrm{~S}_{4}$ nanosheets becomes much rougher after phosphating treatment due to the formation of NiCoP nanoparticles. Moreover, the effects of phosphating conditions on the morphology of the NiCoP/ $\mathrm{NiCo}_{2} \mathrm{~S}_{4}$ materials were also systematically investigated by adjusting the treatment temperature, the reaction time and the mass of $\mathrm{NaH}_{2} \mathrm{PO}_{2}$. As shown in Fig. S2, with the increase of temperature, time and amount of the $\mathrm{P}$ source, more $\mathrm{NiCoP}$ nanoparticles are generated on the $\mathrm{NiCo}_{2} \mathrm{~S}_{4}$ nanosheets. Additionally, the BET surface areas were also tested (Fig. S3). The specific area of $\mathrm{NiCoP} / \mathrm{NiCo}_{2} \mathrm{~S}_{4}$ is $26.2 \mathrm{~m}^{2} \mathrm{~g}^{-1}$, while that of $\mathrm{NiCo}_{2} \mathrm{~S}_{4}$ is $27.3 \mathrm{~m}^{2} \mathrm{~g}^{-1}$. The decrease in specific surface area may be caused by the newly formed NiCoP nanoparticles plugging the pores in the $\mathrm{NiCo}_{2} \mathrm{~S}_{4}$ nanosheets. The formation of heterostructured $\mathrm{NiCoP} / \mathrm{NiCo}_{2} \mathrm{~S}_{4}$ nanosheets was further confirmed by TEM. As shown in Fig. 3c, NiCoP nanoparticles are distributed on the surface of the $\mathrm{NiCo}_{2} \mathrm{~S}_{4}$ nanosheets, which is consistent with the result from SEM analysis. Fig. 3d shows the HRTEM of the $\mathrm{NiCoP} / \mathrm{NiCO}_{2} \mathrm{~S}_{4}$ nanosheet, and the obvious lattice fringes spaced at 0.332 and $0.335 \mathrm{~nm}$, correspond well to the (220) plane of $\mathrm{NiCo}_{2} \mathrm{~S}_{4}$ and (001) plane of NiCoP. The EDS mapping images (Fig. 3e) further confirm that the $\mathrm{Ni}, \mathrm{Co}, \mathrm{S}$ and $\mathrm{P}$ elements are uniformly distributed throughout the $\mathrm{NiCoP} / \mathrm{NiCO}_{2} \mathrm{~S}_{4}$ nanosheet.

The phase of the as-prepared materials was firstly acquired through the analysis of XRD data. As shown in Fig. 4a, the XRD pattern of $\mathrm{NiCoP} / \mathrm{NiCo}_{2} \mathrm{~S}_{4}$ displays well-defined diffraction peaks, which well match with the standard XRD patterns of $\mathrm{NiCo}_{2} \mathrm{~S}_{4}$ (JCPDS No. 73-1704) and NiCoP (JCPDS No. 71-2336), confirming the coexistence of $\mathrm{NiCoP}$ and $\mathrm{NiCo}_{2} \mathrm{~S}_{4}$ after phosphating treatment without any residues or contaminants. Moreover, XPS was further performed to investigate the elemental compositions and valence states of $\mathrm{NiCoP} / \mathrm{NiCo}_{2} \mathrm{~S}_{4}$. As shown in Fig. S4a, there is an extra $\mathrm{P}$ signal in the $\mathrm{NiCoP} /$ $\mathrm{NiCo}_{2} \mathrm{~S}_{4}$ sample compared with the original $\mathrm{NiCo}_{2} \mathrm{~S}_{4}$ sample. In the $\mathrm{Ni} 2 \mathrm{p}$ region (Fig. $4 \mathrm{~b}$ ), the spin orbitals located at 875.4 and $857.4 \mathrm{eV}$ indicate the presence of $\mathrm{Ni}^{3+}$, while the other two peaks centered at 871.1 and $853.8 \mathrm{eV}$ prove the existence of $\mathrm{Ni}^{2+}$ $[36,37]$. In the case of the Co $2 p$ spectrum (Fig. 4c), two strong peaks located at the binding energy of 798.5 and $782.6 \mathrm{eV}$ confirm the presence of $\mathrm{Co}^{2+}$, and the other two peaks at 794.0 and $779.1 \mathrm{eV}$ prove the existence of $\mathrm{Co}^{3+}[38,39]$. Therefore, the chemical composition of the as-prepared materials contain the cations of $\mathrm{Ni}^{2+}, \mathrm{Ni}^{3+}, \mathrm{Co}^{2+}$ and $\mathrm{Co}^{3+}$. As for the $\mathrm{S} 2 \mathrm{p}$ spectrum (Fig. 4d), apart from the shake-up satellite peak at $169.3 \mathrm{eV}$, two peaks are located at $163.0 \mathrm{eV}$ for $\mathrm{S} 2 \mathrm{p}_{1 / 2}$ and $161.8 \mathrm{eV}$ for $\mathrm{S} 2 \mathrm{p}_{3 / 2}$, corresponding to the metal-sulfur (M-S) bonds in the samples $[40,41]$. In the P 2p region (Fig. 4e), the dominant peak located at $134.3 \mathrm{eV}$ indicates that $\mathrm{P}$ exists mainly in the form of phosphate ions. And two peaks at 130.6 and $129.4 \mathrm{eV}$ correspond to $\mathrm{P}$ $2 \mathrm{p}_{1 / 2}$ and $\mathrm{P} 2 \mathrm{p}_{3 / 2}$ spin orbitals $[42,43]$, corresponding to metal phosphides. On the other hand, there is no signal in the P $2 p$ region for pure $\mathrm{NiCo}_{2} \mathrm{~S}_{4}$ sample. These results suggest that the heterostructured $\mathrm{NiCoP} / \mathrm{NiCo}_{2} \mathrm{~S}_{4}$ electrodes have been successfully prepared through the phosphate treatment with the $\mathrm{NaH}_{2} \mathrm{PO}_{2}$ as the phosphorus source.

The electrochemical performances of the as-prepared samples were evaluated on the three-electrode system with $1 \mathrm{~mol} \mathrm{~L}^{-1}$ $\mathrm{KOH}$ as the electrolyte. Fig. 5a shows the comparison cyclic voltammetry (CV) curves of the $\mathrm{NiCo}_{2} \mathrm{O}_{4}, \mathrm{NiCo}_{2} \mathrm{~S}_{4}, \mathrm{NiCoP}$ and $\mathrm{NiCoP} / \mathrm{NiCo}_{2} \mathrm{~S}_{4}$ electrodes at the same scan rate of $10 \mathrm{mV} \mathrm{s}^{-1}$. The current density and integral area of $\mathrm{NiCoP} / \mathrm{NiCo}_{2} \mathrm{~S}_{4}$ are much higher than that of the $\mathrm{NiCo}_{2} \mathrm{O}_{4}, \mathrm{NiCo}_{2} \mathrm{~S}_{4}$, and $\mathrm{NiCoP}$ 

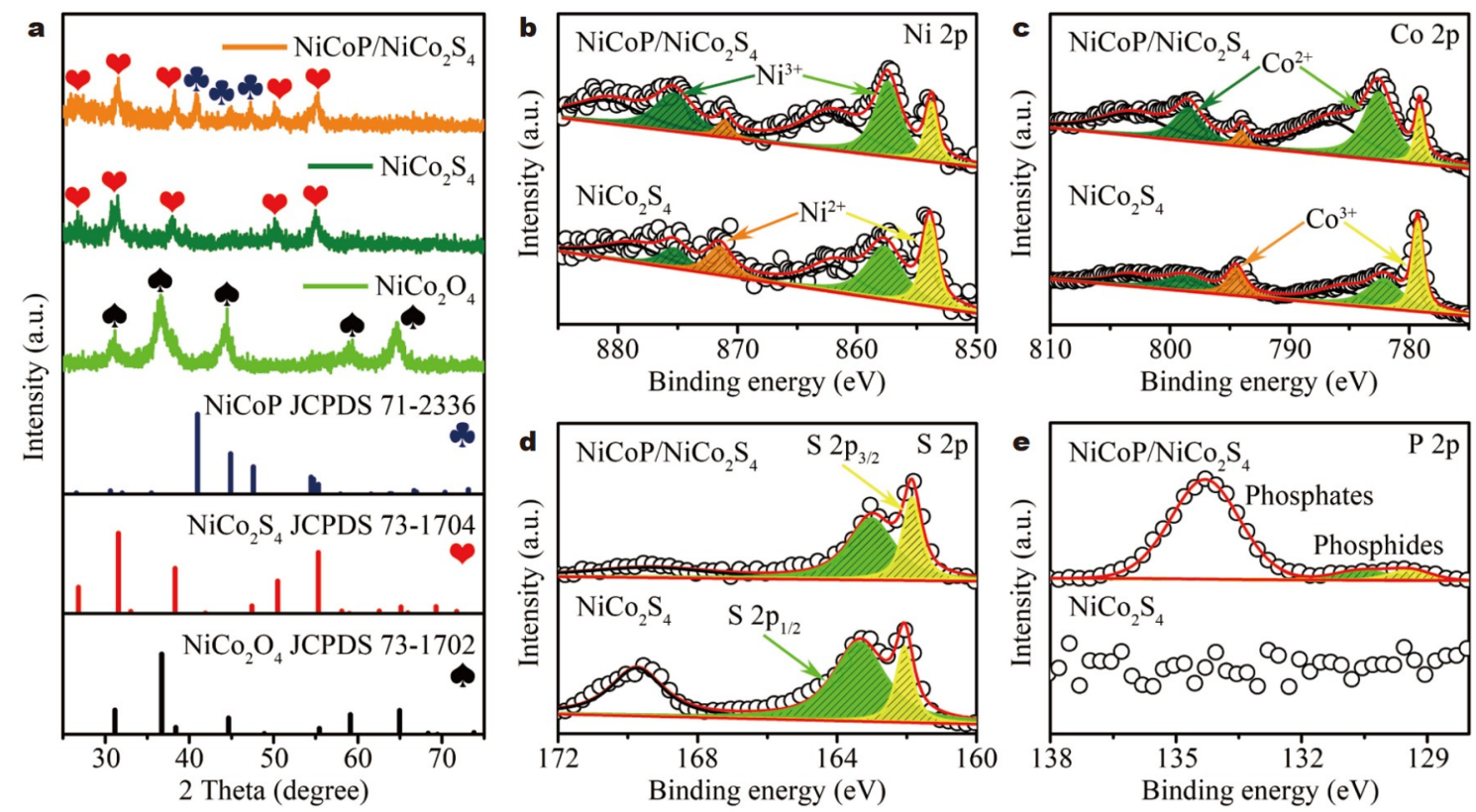

Figure 4 (a) XRD patterns of $\mathrm{NiCo}_{2} \mathrm{O}_{4}, \mathrm{NiCo}_{2} \mathrm{~S}_{4}$ and $\mathrm{NiCoP} / \mathrm{NiCo}_{2} \mathrm{~S}_{4}$. (b) $\mathrm{Ni} 2 \mathrm{p}$, (c) Co $2 \mathrm{p}$, (d) $\mathrm{S} 2 \mathrm{p}$ and (e) P $2 \mathrm{p}$ core-level XPS spectra of $\mathrm{NiCo}_{2} \mathrm{~S}_{4}$ and $\mathrm{NiCoP} / \mathrm{NiCO}_{2} \mathrm{~S}_{4}$.
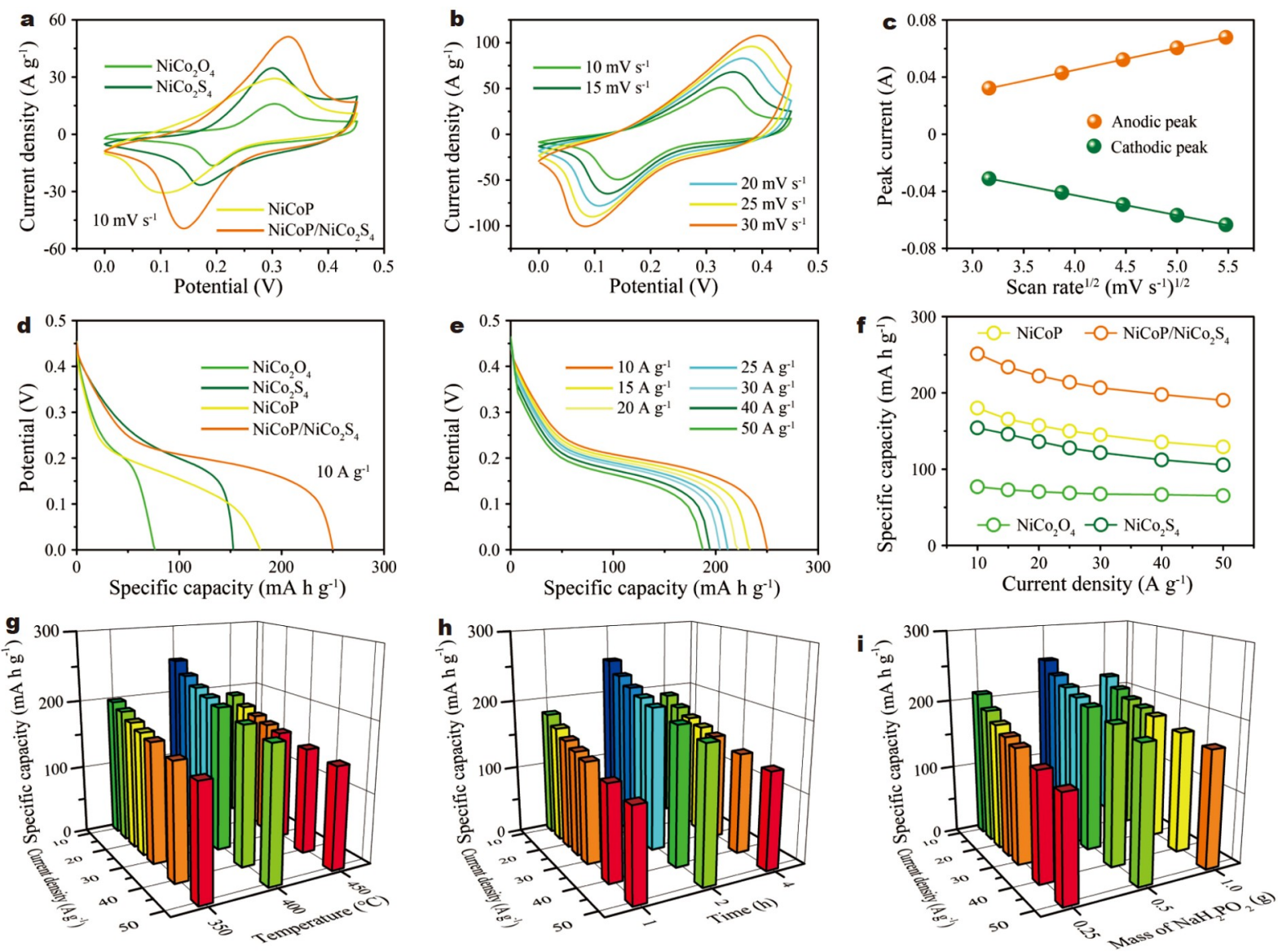

Figure 5 Comparison of (a) CV and (d) discharge curves of the $\mathrm{NiCo}_{2} \mathrm{O}_{4}, \mathrm{NiCo}_{2} \mathrm{~S}_{4}, \mathrm{NiCoP}$ and $\mathrm{NiCoP} / \mathrm{NiCo}_{2} \mathrm{~S}_{4}$ electrodes. (b) CV and (e) discharge curves of the $\mathrm{NiCoP} / \mathrm{NiCo}_{2} \mathrm{~S}_{4}$ electrode. (c) Variation in the redox peak currents with the square root of the scan rates of the NiCoP/NiCo $2 \mathrm{~S}_{4}$ electrode. (f) Specific capacities versus current densities of the $\mathrm{NiCo}_{2} \mathrm{O}_{4}, \mathrm{NiCo}_{2} \mathrm{~S}_{4}, \mathrm{NiCoP}$ and $\mathrm{NiCoP} / \mathrm{NiCo}_{2} \mathrm{~S}_{4}$ electrodes. Specific capacities of the $\mathrm{NiCoP} / \mathrm{NiCo}_{2} \mathrm{~S}_{4}$ electrodes as a function of (g) phosphating temperature, (h) reaction time and (i) mass of $\mathrm{NaH}_{2} \mathrm{PO}_{2}$. 
electrodes, suggesting the enhanced specific capacity and faster redox reaction kinetics. As the scan rate increases from 10 to $30 \mathrm{mV} \mathrm{s}^{-1}$, the $\mathrm{CV}$ curves of $\mathrm{NiCoP} / \mathrm{NiCo}_{2} \mathrm{~S}_{4}$ electrode remain symmetric redox peaks (Fig. $5 \mathrm{~b}$ ), indicating the great reversibility of redox reactions. As shown in Fig. $5 c$, there is a near linear relationship between peak currents and the square root of scan rates, demonstrating that the redox reactions for the $\mathrm{NiCoP} / \mathrm{NiCO}_{2} \mathrm{~S}_{4}$ electrode are diffusion-controlled $[3,36]$. The improved specific capacity can also be achieved by analyzing the discharge curves, as depicted in Fig. 5d, where the discharge plateau of the $\mathrm{NiCoP} / \mathrm{NiCo}_{2} \mathrm{~S}_{4}$ electrode is much longer than others at the same current density of $10 \mathrm{Ag}^{-1}$. Additionally, in contrast to the $\mathrm{NiCo}_{2} \mathrm{O}_{4}, \mathrm{NiCo}_{2} \mathrm{~S}_{4}$, and $\mathrm{NiCoP}$ electrodes, the discharge curves of the heterostructured $\mathrm{NiCoP} / \mathrm{NiCo}_{2} \mathrm{~S}_{4}$ remain steady discharge plateau as the current densities increase from 10 to $50 \mathrm{~A} \mathrm{~g}^{-1}$, indicating the good rate performance (Fig. $5 \mathrm{e}$ and Fig. S5). The highest specific capacity obtained for the NiCoP/ $\mathrm{NiCo}_{2} \mathrm{~S}_{4}$ electrode is $251.1 \mathrm{~mA} \mathrm{~h} \mathrm{~g}^{-1}$ at a high current density of $10 \mathrm{Ag}^{-1}$ (Fig. 5f), which is higher than that of $\mathrm{NiCo}_{2} \mathrm{O}_{4}$ $\left(76.9 \mathrm{mAhg}^{-1}\right), \quad \mathrm{NiCo}_{2} \mathrm{~S}_{4} \quad\left(154.2 \mathrm{mAhg}^{-1}\right)$ and $\mathrm{NiCoP}$ $\left(180.0 \mathrm{~mA} \mathrm{hg}^{-1}\right)$. Importantly, the $\mathrm{NiCoP} / \mathrm{NiCo}_{2} \mathrm{~S}_{4}$ electrode exhibits exceptional capacitive retention at a high current density. Even after increasing the current density to $50 \mathrm{Ag}^{-1}$, the $\mathrm{NiCoP} / \mathrm{NiCO}_{2} \mathrm{~S}_{4}$ electrode shows a capacity of $190.3 \mathrm{~mA} \mathrm{~h}^{-1}$, which is about $76 \%$ retention of that at $10 \mathrm{Ag}^{-1}$. The specific capacity of $\mathrm{NiCoP} / \mathrm{NiCo}_{2} \mathrm{~S}_{4}$ is close or even superior to many similar materials, such as $\mathrm{Co}_{3} \mathrm{~S}_{4}\left(234.0 \mathrm{~mA} \mathrm{~h} \mathrm{~g}^{-1}\right.$ at $\left.8 \mathrm{Ag}^{-1}\right)$ [8], R$\mathrm{Co}_{3} \mathrm{O}_{4} \quad\left(212.6 \mathrm{mAhg}^{-1}\right.$ at $\left.2 \mathrm{~mA} \mathrm{~cm}^{-2}\right)$ [18], $\mathrm{Ni}_{3} \mathrm{~S}_{2} @ \mathrm{PANI}$ $\left(247.6 \mathrm{~mA} \mathrm{~h} \mathrm{~g}^{-1}\right.$ at $\left.11.4 \mathrm{~A} \mathrm{~g}^{-1}\right)$ [44], and $\mathrm{NiCo}_{2} \mathrm{O}_{4}\left(183.1 \mathrm{~mA} \mathrm{~h} \mathrm{~g}^{-1}\right.$ at $1.6 \mathrm{Ag}^{-1}$ ) [45]. Fig. $5 \mathrm{~g}-\mathrm{i}$, Figs $\mathrm{S} 6$ and $\mathrm{S} 7$ show the electrochemical performances of the $\mathrm{NiCoP} / \mathrm{NiCo}_{2} \mathrm{~S}_{4}$ electrode under different phosphating conditions. It is clear that the optimal condition for the $\mathrm{NiCoP} / \mathrm{NiCo}_{2} \mathrm{~S}_{4}$ electrode is $400^{\circ} \mathrm{C}$ for $2 \mathrm{~h}$ with $0.5 \mathrm{~g}$ of $\mathrm{NaH}_{2} \mathrm{PO}_{2}$, which presents the highest specific capacity.

The outstanding specific capacity and high rate capability of the heterostructured $\mathrm{NiCoP} / \mathrm{NiCo}_{2} \mathrm{~S}_{4}$ electrode render it a great potential as the cathode in aqueous $\mathrm{Zn}$-ion battery. An aqueous
$\mathrm{Zn}$-ion battery was assembled by using the $\mathrm{NiCoP} / \mathrm{NiCO}_{2} \mathrm{~S}_{4}$ electrode as the cathode and $\mathrm{Zn}$ plate as the anode with the mixed solution of $1 \mathrm{~mol} \mathrm{~L}^{-1} \mathrm{KOH}$ and $0.01 \mathrm{~mol} \mathrm{~L}^{-1} \mathrm{Zn}\left(\mathrm{CH}_{3}-\right.$ $\mathrm{COO})_{2}$ as the electrolyte. The $\mathrm{NiCoP} / \mathrm{NiCo}_{2} \mathrm{~S}_{4}$ reacts with $\mathrm{OH}^{-}$ on the cathode, while reversible $\mathrm{Zn}(\mathrm{OH})^{2-} / \mathrm{Zn}^{0}$ stripping/plating occurs on the anode (Fig. 6a). Fig. 6b displays the $\mathrm{CV}$ curves of the $\mathrm{NiCoP} / \mathrm{NiCo}_{2} \mathrm{~S}_{4} / / \mathrm{Zn}$ battery at various scan rates. Welldefined symmetric redox peaks can still be observed even at a high scan rate of $60 \mathrm{mV} \mathrm{s}^{-1}$, revealing the highly reversible redox reaction. As shown in the charge-discharge curves of Fig. $6 \mathrm{c}$, the discharge plateau of the $\mathrm{NiCoP} / \mathrm{NiCO}_{2} \mathrm{~S}_{4} / / \mathrm{Zn}$ battery is approximately at $1.7 \mathrm{~V}$. Additionally, the $\mathrm{NiCoP} / \mathrm{NiCo}_{2} \mathrm{~S}_{4} / / \mathrm{Zn}$ battery shows better performances than the $\mathrm{NiCo}_{2} \mathrm{~S}_{4} / / \mathrm{Zn}$ battery (Fig. S8). Particularly, the $\mathrm{NiCoP} / \mathrm{NiCo}_{2} \mathrm{~S}_{4} / / \mathrm{Zn}$ battery exhibits much higher specific capacity than the $\mathrm{NiCo}_{2} \mathrm{~S}_{4} / / \mathrm{Zn}$ battery, which is clearly demonstrated by comparing the CV and discharge curves (Fig. S9). Notably, the $\mathrm{NiCoP} / \mathrm{NiCo}_{2} \mathrm{~S}_{4} / / \mathrm{Zn}$ battery yields an incredibly high specific capacity of $265.1 \mathrm{~mA} \mathrm{~h} \mathrm{~g}^{-1}$ at a high current density of $5 \mathrm{Ag}^{-1}$ (Fig. 6d), which is substantially higher than that of the $\mathrm{NiCo}_{2} \mathrm{~S}_{4} / / \mathrm{Zn}$ battery $\left(144.3 \mathrm{~mA} \mathrm{~h} \mathrm{~g}^{-1}\right)$ and most reported $\mathrm{Zn}$-ion batteries, such as $\mathrm{Ni}(\mathrm{OH})_{2} / \mathrm{CNFs} / / \mathrm{Zn}$ $\left(184 \mathrm{~mA} \mathrm{~h} \mathrm{~g}^{-1}\right.$ at $\left.5 \mathrm{~mA} \mathrm{~cm}^{-2}\right)$ [46], $\mathrm{Co}_{3} \mathrm{O}_{4} / / \mathrm{Zn}\left(162 \mathrm{~mA} \mathrm{~h} \mathrm{~g}^{-1}\right.$ at $1 \mathrm{Ag}^{-1}$ ) [47], $\mathrm{Ni}_{3} \mathrm{~S}_{2} / / \mathrm{Zn}\left(148 \mathrm{mAh} \mathrm{g}^{-1}\right.$ at $0.2 \mathrm{Ag}^{-1}$ ) [48], $\mathrm{NiO} / /$ $\mathrm{ZnO} \quad\left(203 \mathrm{mAhg}^{-1}\right.$ at $\left.0.5 \mathrm{~mA} \mathrm{~cm}^{-2}\right) \quad[14], \quad \mathrm{NiCo}_{2} \mathrm{O}_{4} / / \mathrm{Zn}$ (183.1 $\mathrm{mA} \mathrm{h} \mathrm{g}^{-1}$ at $\left.1.6 \mathrm{~A} \mathrm{~g}^{-1}\right)$ [45], $\mathrm{Zn} / / \mathrm{R}^{-} \mathrm{Co}_{3} \mathrm{O}_{4}\left(240.8 \mathrm{~mA} \mathrm{~h} \mathrm{~g}{ }^{-1}\right.$ at $2 \mathrm{~mA} \mathrm{~cm}^{-2}$ ) [18]. The $\mathrm{NiCoP} / \mathrm{NiCo}_{2} \mathrm{~S}_{4} / / \mathrm{Zn}$ battery possesses a specific capacity of $139.7 \mathrm{~mA} \mathrm{~h} \mathrm{~g}^{-1}$ with $\sim 53 \%$ capacity retention at $10 \mathrm{~A} \mathrm{~g}^{-1}$, indicating its excellent rate capability. The high rate capability of the $\mathrm{NiCoP} / \mathrm{NiCo}_{2} \mathrm{~S}_{4} / / \mathrm{Zn}$ battery was further demonstrated in Fig. 6e, where the current density increased from 5 to $10 \mathrm{~A} \mathrm{~g}^{-1}$ and returned to $5 \mathrm{~A} \mathrm{~g}^{-1}$. The $\mathrm{NiCoP} / \mathrm{NiCo}_{2} \mathrm{~S}_{4} / /$ $\mathrm{Zn}$ battery delivers an average capacity of 264.9, 242.1, 206.2, $175.8,155.2$, and $139.7 \mathrm{mAhg}^{-1}$ at $5,6,7,8,9,10 \mathrm{Ag}^{-1}$, respectively. When the current density is reduced back to $5 \mathrm{~A} \mathrm{~g}^{-1}$ after 50 cycles, the average capacity of $274.4 \mathrm{~mA} \mathrm{~h} \mathrm{~g}^{-1}$ is recovered, revealing excellent rate performance. Fig. $6 \mathrm{f}$ shows the long-term cycling performance of the $\mathrm{NiCoP} / \mathrm{NiCo}_{2} \mathrm{~S}_{4} / / \mathrm{Zn}$ bat-
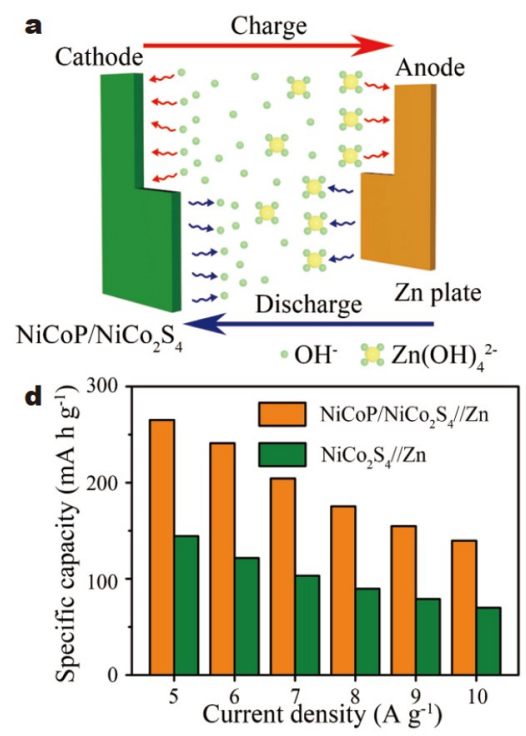
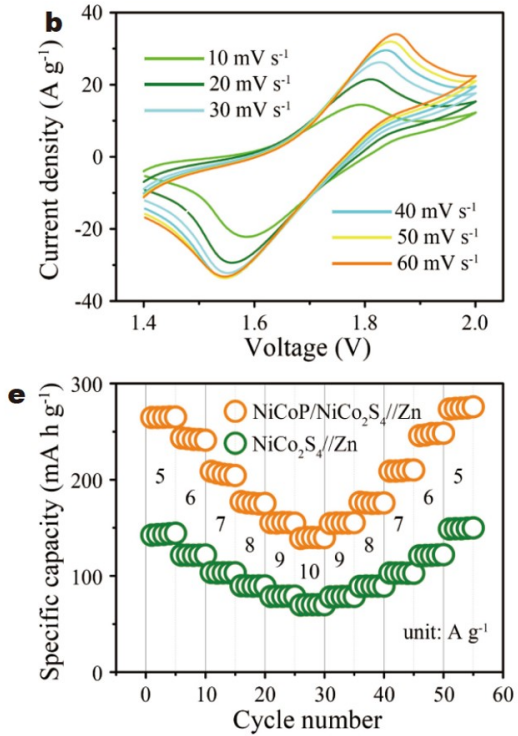
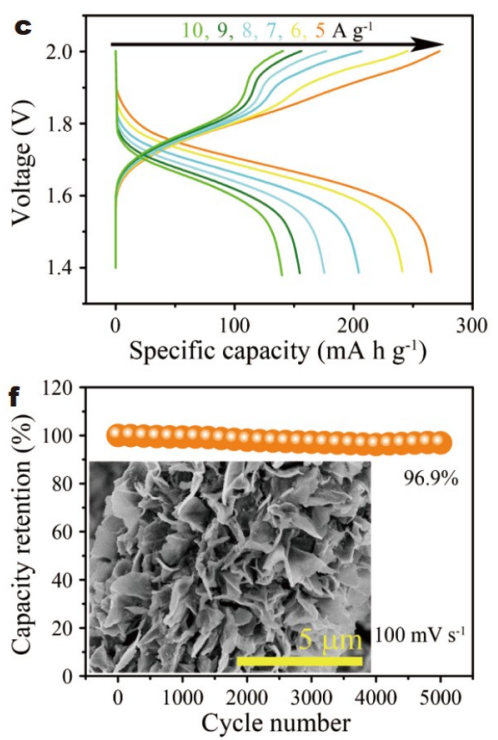

Figure 6 (a) Schematic diagram of the reaction mechanism of the $\mathrm{NiCoP} / \mathrm{NiCo}_{2} \mathrm{~S}_{4} / / \mathrm{Zn}$ battery. (b) $\mathrm{CV}$ and (c) charge-discharge curves of the NiCoP/ $\mathrm{NiCo}_{2} \mathrm{~S}_{4} / / \mathrm{Zn}$ battery. (d) Specific capacities versus current densities and (e) rate performances of the $\mathrm{NiCo}_{2} \mathrm{~S}_{4} / / \mathrm{Zn}$ and $\mathrm{NiCoP}_{2} / \mathrm{NiCo}_{2} \mathrm{~S}_{4} / / \mathrm{Zn}$ batteries. (f) Cycling test of the $\mathrm{NiCoP} / \mathrm{NiCo}_{2} \mathrm{~S}_{4} / / \mathrm{Zn}$ battery and the SEM image of the $\mathrm{NiCoP} / \mathrm{NiCo}_{2} \mathrm{~S}_{4}$ cathode after 5000 cycles (inset). 


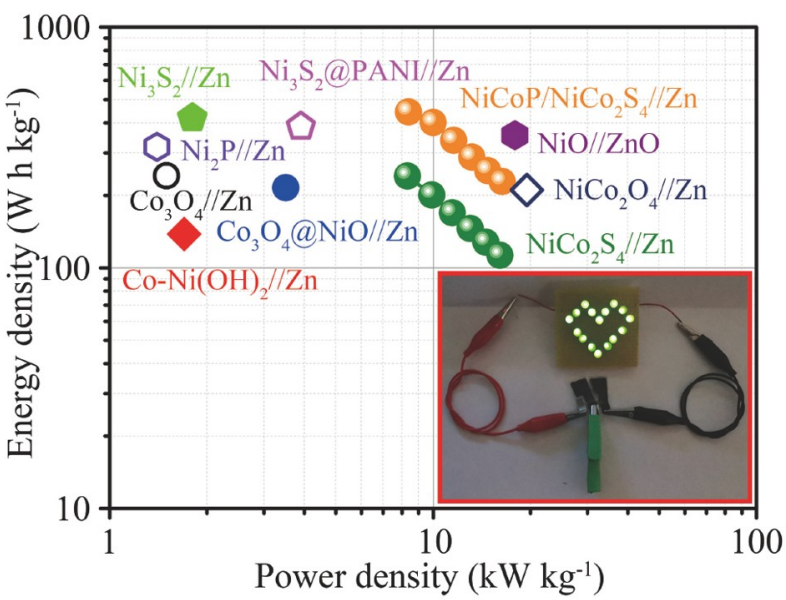

Figure 7 Ragone plots of the $\mathrm{NiCo}_{2} \mathrm{~S}_{4} / / \mathrm{Zn}$ battery and $\mathrm{NiCoP} / \mathrm{NiCo}_{2} \mathrm{~S}_{4} / / \mathrm{Zn}$ battery compared with other similar studies. The inset is the digital photo of heart-shaped LEDs powered by two as-fabricated $\mathrm{NiCoP} / \mathrm{NiCo}_{2} \mathrm{~S}_{4} / / \mathrm{Zn}$ batteries in series.

tery collected at a high scan rate of $100 \mathrm{mV} \mathrm{s}^{-1}$. The $\mathrm{NiCoP} /$ $\mathrm{NiCo}_{2} \mathrm{~S}_{4} / / \mathrm{Zn}$ battery maintains $96.9 \%$ of the initial capacity after 5000 cycles. The $\mathrm{NiCoP} / \mathrm{NiCo}_{2} \mathrm{~S}_{4}$ nanosheet arrays are wellreserved (inset in Fig. 6f), further demonstrating the excellent cycling performance.

Energy density and power density are two important parameters to estimate the practicability of energy storage devices. Fig. 7 shows the Ragone plots of the as-assembled $\mathrm{NiCo}_{2} \mathrm{~S}_{4} / / \mathrm{Zn}$ battery and $\mathrm{NiCoP} / \mathrm{NiCo}_{2} \mathrm{~S}_{4} / / \mathrm{Zn}$ battery. It can be observed that the $\mathrm{NiCoP} / \mathrm{NiCo}_{2} \mathrm{~S}_{4} / / \mathrm{Zn}$ battery delivers a maximum energy density of $444.7 \mathrm{~W} \mathrm{~h} \mathrm{~kg}^{-1}$ at the power density of $8.4 \mathrm{~kW} \mathrm{~kg}^{-1}$. When the power density is increased to $16.3 \mathrm{~kW} \mathrm{~kg}^{-1}$, the energy density still remains $228.2 \mathrm{Wh} \mathrm{kg}^{-1}$. While the $\mathrm{NiCo}_{2} \mathrm{~S}_{4} / / \mathrm{Zn}$ battery only delivers a maximum energy density of $240.5 \mathrm{~W} \mathrm{~h} \mathrm{~kg}^{-1}$ at the power density of $8.3 \mathrm{~kW} \mathrm{~kg}^{-1}$. The energy density of the obtained $\mathrm{NiCoP} / \mathrm{NiCo}_{2} \mathrm{~S}_{4} / / \mathrm{Zn}$ battery is close to or even higher than those of some aqueous $\mathrm{Zn}$-ion batteries reported previously, such as $\mathrm{NiO} / / \mathrm{ZnO}\left(355.7 \mathrm{Wh} \mathrm{kg}^{-1}\right.$ at $17.9 \mathrm{~kW} \mathrm{~kg}^{-1}$ ) [14], $\mathrm{Ni}_{2} \mathrm{P} / / \mathrm{Zn} \quad\left(318.0 \mathrm{Wh} \mathrm{kg}^{-1}\right.$ at $\left.1.4 \mathrm{~kW} \mathrm{~kg}^{-1}\right)$ [49], $\mathrm{Ni}_{3} \mathrm{~S}_{2} / / \mathrm{Zn}$ (419.6 Wh kg-1 at $1.8 \mathrm{~kW} \mathrm{~kg}^{-1}$ ) [48], $\mathrm{Ni}_{3} \mathrm{~S}_{2} @$ $\mathrm{PANI} / / \mathrm{Zn} \quad\left(386.7 \mathrm{Wh} \mathrm{kg}^{-1}\right.$ at $\left.3.9 \mathrm{~kW} \mathrm{~kg}^{-1}\right)$ [44], $\quad \mathrm{Co}_{3} \mathrm{O}_{4} / / \mathrm{Zn}$ $\left(241.0 \mathrm{Wh} \mathrm{kg}^{-1}\right.$ at $\left.1.5 \mathrm{~kW} \mathrm{~kg}^{-1}\right)$ [47], $\mathrm{Co}_{3} \mathrm{O}_{4} @ \mathrm{NiO} / / \mathrm{Zn}$ $\left(215.5 \mathrm{~W} \mathrm{~h} \mathrm{~kg}^{-1}\right.$ at $\left.3.5 \mathrm{~kW} \mathrm{~kg}^{-1}\right) \quad$ [50], $\quad \mathrm{NiCo}_{2} \mathrm{O}_{4} / / \mathrm{Zn}$ $\left(210.7 \mathrm{Wh} \mathrm{kg}^{-1}\right.$ at $\left.19.5 \mathrm{~kW} \mathrm{~kg}^{-1}\right)$ [45], and $\mathrm{Co}-\mathrm{Ni}(\mathrm{OH})_{2} / / \mathrm{Zn}$ (138.0 $\mathrm{W} \mathrm{h} \mathrm{kg}^{-1}$ at $1.7 \mathrm{~kW} \mathrm{~kg}^{-1}$ ) [51]. The inset of Fig. 7 shows that two as-fabricated batteries connected in series can effectively power heart-shaped light-emitting diodes (LEDs) indicators, demonstrating the great promise for potential practical utilization.

\section{CONCLUSION}

In summary, we report the synthesis of heterostructured $\mathrm{NiCoP} /$ $\mathrm{NiCo}_{2} \mathrm{~S}_{4}$ nanosheet arrays on carbon cloth through treating $\mathrm{NiCo}_{2} \mathrm{~S}_{4}$ nanosheet arrays in the presence of $\mathrm{P}$ source, and demonstrate its excellent property as the electrode material in aqueous $\mathrm{Zn}$-ion batteries. The high electrochemical activity between $\mathrm{NiCoP}$ and $\mathrm{NiCo}_{2} \mathrm{~S}_{4}$ enables fast electron transport and rapid ion diffusion. As a result, the $\mathrm{NiCoP} / \mathrm{NiCo}_{2} \mathrm{~S}_{4}$ electrode shows a large specific capacity of $251.1 \mathrm{~mA} \mathrm{~h} \mathrm{~g}^{-1}$ at a high current density of $10 \mathrm{Ag}^{-1}$ and satisfactory rate capability (retaining about $76 \%$ even at $50 \mathrm{~A} \mathrm{~g}^{-1}$ ). Furthermore, the assembled NiCoP/ $\mathrm{NiCo}_{2} \mathrm{~S}_{4} / / \mathrm{Zn}$ battery delivers a high specific capacity of $265.1 \mathrm{~mA} \mathrm{~h} \mathrm{~g}^{-1}$ at $5 \mathrm{Ag} \mathrm{g}^{-1}$, excellent cycling stability with $96.9 \%$ retention after 5000 cycles, as well as a competitive energy density of $444.7 \mathrm{Wh} \mathrm{kg}^{-1}$ at the power density of $8.4 \mathrm{~kW} \mathrm{~kg}^{-1}$. The successful construction of aqueous $\mathrm{Zn}$-ion batteries by interfacial engineering of electrode materials sheds light on the exploration of high-performance energy storage devices in the future.

Received 29 April 2021; accepted 10 June 2021; published online 12 August 2021

1 Chen Y, Zhang W, Zhou D, et al. Co-Fe mixed metal phosphide nanocubes with highly interconnected-pore architecture as an efficient polysulfide mediator for lithium-sulfur batteries. ACS Nano, 2019, 13: 4731-4741

2 Fang G, Zhou J, Pan A, et al. Recent advances in aqueous zinc-ion batteries. ACS Energy Lett, 2018, 3: 2480-2501

3 Shen Y, Li Z, Cui Z, et al. Boosting the interface reaction activity and kinetics of cobalt molybdate by phosphating treatment for aqueous zinc-ion batteries with high energy density and long cycle life. J Mater Chem A, 2020, 8: 21044-21052

4 Liu J, Wang J, Ku Z, et al. Aqueous rechargeable alkaline $\mathrm{Co}_{x} \mathrm{Ni}_{2-x} \mathrm{~S}_{2}$ / $\mathrm{TiO}_{2}$ battery. ACS Nano, 2016, 10: 1007-1016

5 Tang B, Shan L, Liang S, et al. Issues and opportunities facing aqueous zinc-ion batteries. Energy Environ Sci, 2019, 12: 3288-3304

6 Zhang $\mathrm{K}$, Ye X, Shen $\mathrm{Y}$, et al. Interface engineering of $\mathrm{Co}_{3} \mathrm{O}_{4}$ nanowire arrays with ultrafine $\mathrm{NiO}$ nanowires for high-performance rechargeable alkaline batteries. Dalton Trans, 2020, 49: 8582-8590

7 Huang M, Li M, Niu C, et al. Recent advances in rational electrode designs for high-performance alkaline rechargeable batteries. Adv Funct Mater, 2019, 29: 1807847

8 Zhang SW, Yin BS, Luo YZ, et al. Fabrication and theoretical investigation of cobaltosic sulfide nanosheets for flexible aqueous $\mathrm{Zn} / \mathrm{Co}$ batteries. Nano Energy, 2020, 68: 104314

9 Liu J, Chen M, Zhang L, et al. A flexible alkaline rechargeable $\mathrm{Ni} / \mathrm{Fe}$ battery based on graphene foam/carbon nanotubes hybrid film. Nano Lett, 2014, 14: 7180-7187

10 Jiao Y, Hong $\mathrm{W}$, Li $\mathrm{P}$, et al. Metal-organic framework derived $\mathrm{Ni} / \mathrm{NiO}$ micro-particles with subtle lattice distortions for high-performance electrocatalyst and supercapacitor. Appl Catal B-Environ, 2019, 244: 732-739

11 Kim H, Jeong G, Kim YU, et al. Metallic anodes for next generation secondary batteries. Chem Soc Rev, 2013, 42: 9011-9034

12 Liu F, Chen Z, Fang G, et al. $\mathrm{V}_{2} \mathrm{O}_{5}$ nanospheres with mixed vanadium valences as high electrochemically active aqueous zinc-ion battery cathode. Nano-Micro Lett, 2019, 11: 25

13 Hu P, Wang T, Zhao J, et al. Ultrafast alkaline Ni/Zn battery based on $\mathrm{Ni}$-foam-supported $\mathrm{Ni}_{3} \mathrm{~S}_{2}$ nanosheets. ACS Appl Mater Interfaces, 2015, 7: 26396-26399

14 Liu J, Guan C, Zhou C, et al. A flexible quasi-solid-state nickel-zinc battery with high energy and power densities based on 3D electrode design. Adv Mater, 2016, 28: 8732-8739

15 Zeng Y, Meng Y, Lai Z, et al. An ultrastable and high-performance flexible fiber-shaped $\mathrm{Ni}-\mathrm{Zn}$ battery based on a $\mathrm{Ni}-\mathrm{NiO}$ heterostructured nanosheet cathode. Adv Mater, 2017, 29: 1702698

16 Tang Y, Li X, Lv $\mathrm{H}$, et al. Stabilized $\mathrm{Co}^{3+} / \mathrm{Co}^{4+}$ redox pair in in situ produced $\mathrm{CoSe}_{2-x}$-derived cobalt oxides for alkaline $\mathrm{Zn}$ batteries with 10 000-cycle lifespan and 1.9-V voltage plateau. Adv Energy Mater, 2020, 10: 2000892

17 Gong M, Li Y, Zhang H, et al. Ultrafast high-capacity NiZn battery with nialco-layered double hydroxide. Energy Environ Sci, 2014, 7: 20252032

18 Lu Y, Wang J, Zeng S, et al. An ultrathin defect-rich $\mathrm{Co}_{3} \mathrm{O}_{4}$ nanosheet cathode for high-energy and durable aqueous zinc ion batteries. J Mater Chem A, 2019, 7: 21678-21683 
19 Caldeira V, Rouget R, Fourgeot F, et al. Controlling the shape change and dendritic growth in $\mathrm{Zn}$ negative electrodes for application in $\mathrm{Zn} / \mathrm{Ni}$ batteries. J Power Sources, 2017, 350: 109-116

20 Shen Y, Zhang K, Yang F, et al. Oxygen vacancies-rich cobalt-doped $\mathrm{NiMoO}_{4}$ nanosheets for high energy density and stable aqueous $\mathrm{Ni}-\mathrm{Zn}$ battery. Sci China Mater, 2020, 63: 1205-1215

21 Xiao J, Wan L, Yang S, et al. Design hierarchical electrodes with highly conductive $\mathrm{NiCo}_{2} \mathrm{~S}_{4}$ nanotube arrays grown on carbon fiber paper for high-performance pseudocapacitors. Nano Lett, 2014, 14: 831-838

22 Shen $\mathrm{L}, \mathrm{Yu} \mathrm{L}, \mathrm{Wu} \mathrm{HB}$, et al. Formation of nickel cobalt sulfide ball-inball hollow spheres with enhanced electrochemical pseudocapacitive properties. Nat Commun, 2015, 6: 6694

23 Guan BY, Yu L, Wang X, et al. Formation of onion-like $\mathrm{NiCo}_{2} \mathrm{~S}_{4}$ particles via sequential ion-exchange for hybrid supercapacitors. Adv Mater, 2017, 29: 1605051

24 Zeng W, Zhang G, Wu X, et al. Construction of hierarchical CoS nanowire@ $\mathrm{NiCo}_{2} \mathrm{~S}_{4}$ nanosheet arrays via one-step ion exchange for highperformance supercapacitors. J Mater Chem A, 2015, 3: 24033-24040

25 Anwer H, Lee H, Kim HR, et al. Selective transport and separation of charge-carriers by an electron transport layer in $\mathrm{NiCo}_{2} \mathrm{~S}_{4} / \mathrm{CdO} @ \mathrm{CC}$ for excellent water splitting. Appl Catal B-Environ, 2020, 265: 118564

26 Chen X, Chen D, Guo X, et al. Facile growth of caterpillar-like $\mathrm{NiCo}_{2} \mathrm{~S}_{4}$ nanocrystal arrays on nickle foam for high-performance supercapacitors. ACS Appl Mater Interfaces, 2017, 9: 18774-18781

27 Shen $\mathrm{Y}$, Zhang $\mathrm{K}$, Chen B, et al. Enhancing the electrochemical performance of nickel cobalt sulfides hollow nanospheres by structural modulation for asymmetric supercapacitors. J Colloid Interface Sci, 2019, 557: 135-143

28 Han C, Zhang T, Li J, et al. Enabling flexible solid-state Zn batteries via tailoring sulfur deficiency in bimetallic sulfide nanotube arrays. Nano Energy, 2020, 77: 105165

29 Huang J, Xiong Y, Peng Z, et al. A general electrodeposition strategy for fabricating ultrathin nickel cobalt phosphate nanosheets with ultrahigh capacity and rate performance. ACS Nano, 2020, 14: 14201-14211

30 Liang H, Gandi AN, Anjum DH, et al. Plasma-assisted synthesis of NiCoP for efficient overall water splitting. Nano Lett, 2016, 16: 77187725

31 Nguyen TT, Balamurugan J, Kim NH, et al. Hierarchical 3D Zn-Ni-P nanosheet arrays as an advanced electrode for high-performance allsolid-state asymmetric supercapacitors. J Mater Chem A, 2018, 6: 86698681

32 Tian J, Liu Q, Asiri AM, et al. Self-supported nanoporous cobalt phosphide nanowire arrays: An efficient 3D hydrogen-evolving cathode over the wide range of $\mathrm{pH}$ 0-14. J Am Chem Soc, 2014, 136: 7587-7590

33 Song $\mathrm{W}, \mathrm{Wu} J$, Wang $\mathrm{G}$, et al. Rich-mixed-valence $\mathrm{Ni}_{x} \mathrm{Co}_{3-x} \mathrm{P}_{y}$ porous nanowires interwelded junction-free 3D network architectures for ultrahigh areal energy density supercapacitors. Adv Funct Mater, 2018, 28: 1804620

34 Zhang $\mathrm{N}, \mathrm{Li} \mathrm{Y}, \mathrm{Xu}$ J, et al. High-performance flexible solid-state asymmetric supercapacitors based on bimetallic transition metal phosphide nanocrystals. ACS Nano, 2019, 13: 10612-10621

35 Li Y, Tan X, Tan $\mathrm{H}$, et al. Phosphine vapor-assisted construction of heterostructured $\mathrm{Ni}_{2} \mathrm{P} / \mathrm{NiTe}_{2}$ catalysts for efficient hydrogen evolution. Energy Environ Sci, 2020, 13: 1799-1807

36 Zeng Y, Lai Z, Han Y, et al. Oxygen-vacancy and surface modulation of ultrathin nickel cobaltite nanosheets as a high-energy cathode for advanced $\mathrm{Zn}$-ion batteries. Adv Mater, 2018, 30: 1802396

37 Chu W, Shi Z, Hou Y, et al. Trifunctional of phosphorus-doped $\mathrm{NiCo}_{2} \mathrm{O}_{4}$ nanowire materials for asymmetric supercapacitor, oxygen evolution reaction, and hydrogen evolution reaction. ACS Appl Mater Interfaces, 2020, 12: 2763-2772

38 Tang S, Zhu B, Shi X, et al. General controlled sulfidation toward achieving novel nanosheet-built porous square- $\mathrm{FeCo}_{2} \mathrm{~S}_{4}$-tube arrays for high-performance asymmetric all-solid-state pseudocapacitors. Adv Energy Mater, 2017, 7: 1601985

39 Wang $\mathrm{Y}$, Chen $\mathrm{Z}$, Lei $\mathrm{T}$, et al. Hollow $\mathrm{NiCo}_{2} \mathrm{~S}_{4}$ nanospheres hybridized with $3 \mathrm{D}$ hierarchical porous $\mathrm{rGO} / \mathrm{Fe}_{2} \mathrm{O}_{3}$ composites toward high-performance energy storage device. Adv Energy Mater, 2018, 8: 1703453
40 Guan B, Li Y, Yin B, et al. Synthesis of hierarchical NiS microflowers for high performance asymmetric supercapacitor. Chem Eng J, 2017, 308: 1165-1173

41 Ye C, Zhang L, Guo C, et al. A 3D hybrid of chemically coupled nickel sulfide and hollow carbon spheres for high performance lithium-sulfur batteries. Adv Funct Mater, 2017, 27: 1702524

42 Chen HC, Jiang S, Xu B, et al. Sea-urchin-like nickel-cobalt phosphide/ phosphate composites as advanced battery materials for hybrid supercapacitors. J Mater Chem A, 2019, 7: 6241-6249

43 Li S, Yang N, Liao L, et al. Doping $\beta-\mathrm{CoMoO}_{4}$ nanoplates with phosphorus for efficient hydrogen evolution reaction in alkaline media. ACS Appl Mater Interfaces, 2018, 10: 37038-37045

44 Zhou L, Zhang X, Zheng D, et al. $\mathrm{Ni}_{3} \mathrm{~S}_{2} @$ PANI core-shell nanosheets as a durable and high-energy binder-free cathode for aqueous rechargeable nickel-zinc batteries. J Mater Chem A, 2019, 7: 10629-10635

45 Zhang $\mathrm{H}$, Zhang $\mathrm{X}$, Li $\mathrm{H}$, et al. Flexible rechargeable $\mathrm{Ni} / / \mathrm{Zn}$ battery based on self-supported $\mathrm{NiCo}_{2} \mathrm{O}_{4}$ nanosheets with high power density and good cycling stability. Green Energy Environ, 2018, 3: 56-62

46 Jian $\mathrm{Y}$, Wang $\mathrm{D}$, Huang $\mathrm{M}$, et al. Facile synthesis of $\mathrm{Ni}(\mathrm{OH})_{2} /$ carbon nanofiber composites for improving NiZn battery cycling life. ACS Sustain Chem Eng, 2017, 5: 6827-6834

47 Wang $\mathrm{X}$, Wang $\mathrm{F}$, Wang $\mathrm{L}$, et al. An aqueous rechargeable $\mathrm{Zn} / / \mathrm{Co}_{3} \mathrm{O}_{4}$ battery with high energy density and good cycling behavior. Adv Mater, 2016, 28: 4904-4911

48 He Y, Zhang $\mathrm{P}$, Huang $\mathrm{H}$, et al. Engineering sulfur vacancies of $\mathrm{Ni}_{3} \mathrm{~S}_{2}$ nanosheets as a binder-free cathode for an aqueous rechargeable Ni-Zn battery. ACS Appl Energy Mater, 2020, 3: 3863-3875

49 Wen J, Feng $\mathrm{Z}$, Liu $\mathrm{H}$, et al. In-situ synthesized $\mathrm{Ni}_{2} \mathrm{P}$ nanosheet arrays as the cathode for novel alkaline Ni//Zn rechargeable battery. Appl Surf Sci, 2019, 485: 462-467

$50 \mathrm{Lu} \mathrm{Z}, \mathrm{Wu} \mathrm{X}$, Lei X, et al. Hierarchical nanoarray materials for advanced nickel-zinc batteries. Inorg Chem Front, 2015, 2: 184-187

51 Xu C, Liao J, Yang C, et al. An ultrafast, high capacity and superior longevity $\mathrm{Ni} / \mathrm{Zn}$ battery constructed on nickel nanowire array film. Nano Energy, 2016, 30: 900-908

Acknowledgements This work was supported by the National Natural Science Foundation of China (51602049 and 51708504), and China Postdoctoral Science Foundation (2017M610217 and 2018T110322).

Author contributions Yang F and Shen Y performed the experiments and wrote the article; Cen $\mathrm{Z}$ and Wan J conducted the characterization and data analyses; $\mathrm{Li} \mathrm{S}, \mathrm{He} \mathrm{G}, \mathrm{Hu} \mathrm{J}$ and $\mathrm{Xu} \mathrm{K}$ proposed the experimental design and wrote the paper. All authors contributed to the general discussion.

Conflict of interest The authors declare that they have no conflict of interest.

Supplementary information Supporting data are available in the online version of the paper.

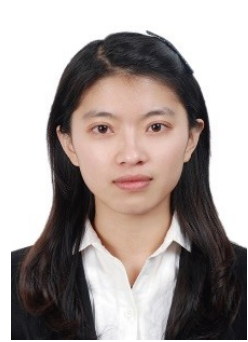

Fang Yang received her $\mathrm{PhD}$ degree from Donghua University in 2015. Currently, she works at the School of Mechanical and Automotive Engineering at Shanghai University of Engineering Science. Her research focuses on rational design and synthesis of nanocomposite materials for energy storage devices. 


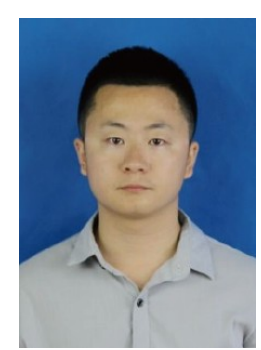

Shijie Li received his $\mathrm{PhD}$ degree in environmental engineering from Donghua University in 2014. He is currently an associate professor at the National Engineering Research Center for Marine Aquaculture, Zhejiang Ocean University. His research interests focus on the development of functional nanomaterials and their applications in electrochemical energy storage and conversion, and environmental remediation.

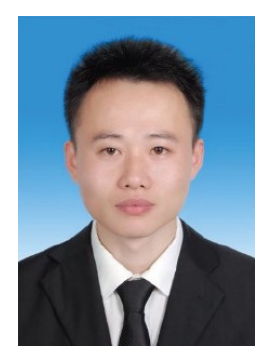

Kaibing Xu received his $\mathrm{PhD}$ degree from Donghua University in 2015. Currently, he works at the Research Center for Analysis and Measurement, Donghua University. His research focuses on rational design and synthesis of nanocomposite materials for applications in electrochemical energy storage and conversion such as supercapacitors, alkaline rechargeable batteries and lithium ion batteries.

\section{原位构筑富异质结界面的双金属硫/磷化合物提升水 系锌电池性能}

杨方 ${ }^{1}$, 沈越年 ${ }^{2}$, 岑泽 $^{1}$, 万杰 $^{1}$, 李世杰 ${ }^{3 *}$, 何冠杰 ${ }^{4}$, 胡俊青 ${ }^{2,5}$, 徐开兵 ${ }^{2 *}$

摘要 目前开发高倍率和稳定的水系锌离子电池电极材料仍然是一个 挑战. 本研究提出了一种磷化辅助界面工程策略, 将 $\mathrm{NiCo}_{2} \mathrm{~S}_{4}$ 纳米片可 控转化为 $\mathrm{NiCoP} / \mathrm{NiCo}_{2} \mathrm{~S}_{4}$ 异质结构作为水系锌离子电池电极材料. 具有 丰富界面的多组分异质结构不仅提高了电极材料的电导率, 而且增强 了锌离子的扩散路径. 和预期结果一样, $\mathrm{NiCoP} / \mathrm{NiCo}_{2} \mathrm{~S}_{4}$ 电极材料在 $10 \mathrm{~A} \mathrm{~g}^{-1}$ 的电流密度下其容量高达 $251.1 \mathrm{~mA} \mathrm{~h} \mathrm{~g}^{-1}$, 且具有优异的倍率性 能 (电流密度高达 $50 \mathrm{~A} \mathrm{~g}^{-1}$ 时, 其容量保持约为 $76 \%$ ). 此外, 以 $\mathrm{NiCoP} /$ $\mathrm{NiCo}_{2} \mathrm{~S}_{4}$ 为正极组装的锌离子电池也展现了优异的比容量(在 $5 \mathrm{~A} \mathrm{~g}^{-1}$ 的 电流密度下高达 $265.1 \mathrm{~mA} \mathrm{~h} \mathrm{~g}^{-1}$ ), 长循环稳定性(经过5000圈循环后比容 量保持率为 $96.9 \%$ ) 和高能量密度 (在 $8.4 \mathrm{~kW} \mathrm{~kg}^{-1}$ 的功率密度下高达 $444.7 \mathrm{~W} \mathrm{~h} \mathrm{~kg}^{-1}$ ). 因此, 本研究为构建具有丰富界面的异质结电极材料 提供了一种简单的磷化辅助界面工程策略, 为未来开发高性能储能器 件提供了理论基础. 